\title{
Mapping application for Greater Bandung Area using Web \\ Technology
}

DOI:10.36909/jer.ASSEEE.16093

\author{
Eko Budi Setiawan*, Angga Setiyadi \\ Departemen Teknik Informatika, Universitas Komputer Indonesia, Indonesia \\ *Corresponding Author : eko@email.unikom.ac.id
}

\begin{abstract}
Mapping is needed to determine the condition of spatial data and non-spatial data from an area. This research produces a mapping application based on geographic information systems that display spatial data and boundaries of 888 villages located in the Greater Bandung Area, which consists of Bandung City, Cimahi City, Bandung Regency, West Bandung Regency, and Sumedang Regency. The method used is the Software Development Life Cycle with Waterfall model. The technology used is the application programming interface from Openstreet MapBox and ArcGIS. Based on testing applications that can access online found that the application built can $100 \%$ display the mapping of all areas in the Greater Bandung Area to the district level. This research is useful for developing the tourism and creative industries of MSMEs based on each region's geographical conditions, both for the community and the government.
\end{abstract}

Keywords: mapping, information systems, spatial, Greater Bandung Area.

\section{INTRODUCTION}

Mapping an area is needed to determine the condition of the area, both spatially and nonspatially. Various objectives can be obtained by mapping an area. Census activities (Tsutsumida et al., 2019), mapping workers (Ullerud et al., 2018), population (Humphries et al., 2017), and migration (Brovelli et al., 2017). With the mapping application, it is easier for users to see the information needed to obtain information in spatial and spatial form. 
This research discusses applications for area mapping in the Greater Bandung area. In contrast to several mapping applications, which usually only designate one area (Alkhalidi et al., 2020; Setiawan et al., 2019). Mapping in this research was generally carried out in four major areas in Greater Bandung. The mapping that has been done so far can display spatial data from 888 villages. Therefore, it is different from other studies that only display specific information on the city of Bandung, such as information on the level of crime (Dede et al., 2017) or 3Dimensional maps (Maulana et al., 2019), as well as mapping of smart villages which only specifically for one village only (Marlintha et al., 2017). This study uses a different technology from several studies that have been conducted because the coverage of the research area is quite extensive. Hence, it is necessary to use the right technique so that the application is not too heavy when accessed online.

The method used to build this application is the Software Development Life Cycle with a waterfall model, often used when building applications (Saxena, 2019). This mapping application was built on a web basis with the PHP programming language. The technology used is the application programming interface provided by OpenStreetMap Mapbox, commonly used for mapping (Syaifudin et al.,2019), and ArcGIS, which is used for processing coordinate data (Falah \& Zeinivand, 2019). This research aims to make it easier for users to find spatial information from the Greater Bandung area. The benefits of this research in the future can be used for various fields, one of which is the creative industry sector of MSMEs and tourism.

\section{METHOD}

In general, the research method consists of two stages. The first stage is data collection, while the second stage is the software development of the waterfall model life cycle. Figure 1 represents the stages of the research method carried out. 


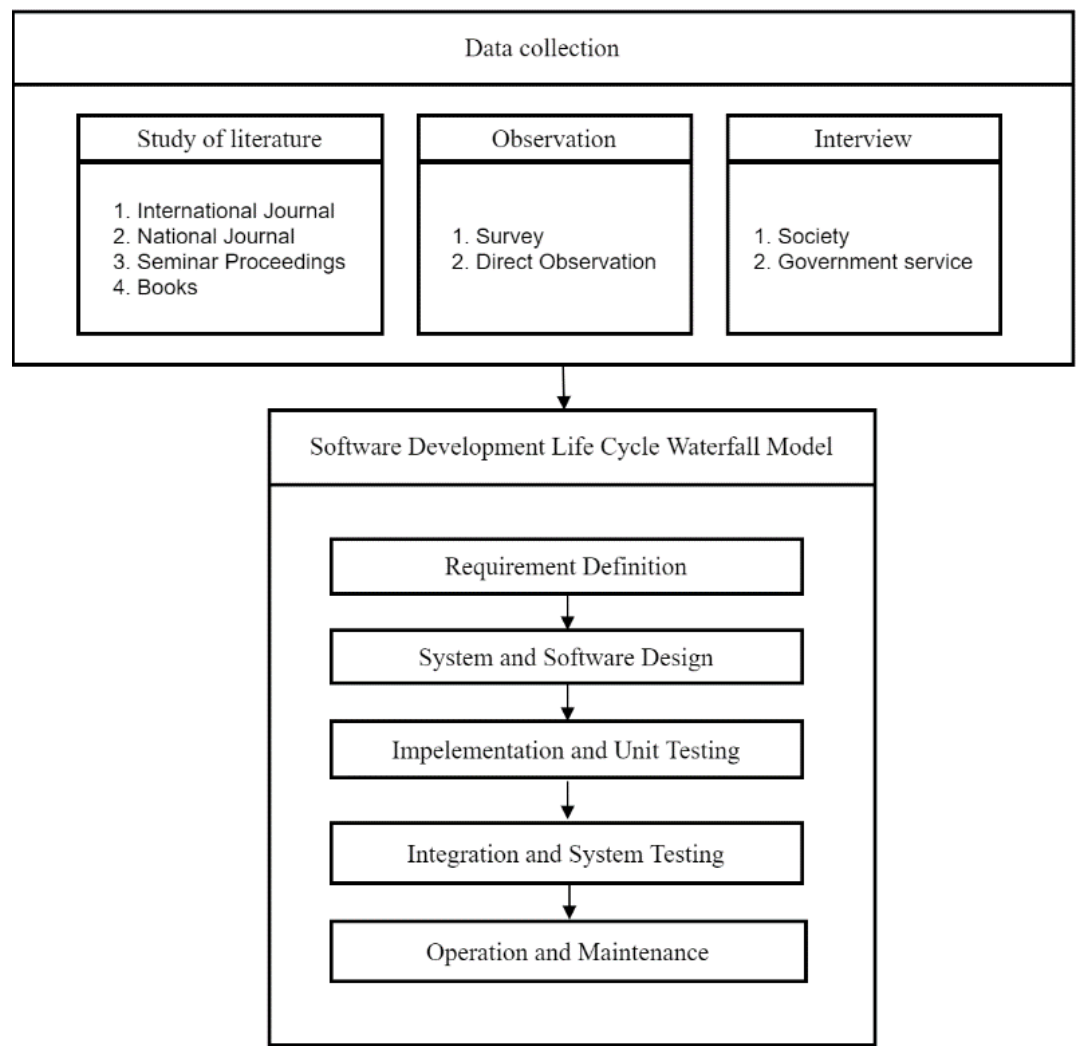

Figure 1 Stages of the research carried out

\section{Data Collection Stages}

This stage was the initial stage when carrying out research. This initial stage consists of a literature study, observation, and interviews. Literature studies consist of collecting information from journals, proceedings, and reference books (Orlando et al.,2020). Another stage was observed. This research is intended for use by the general public and government agencies. Direct surveys and observations are carried out to ensure that other sources' spatial data is valid. This direct observation needs to be done to combine the available data sources with (Smith \& Sparkes, 2016) the survey results. This research stage results from the latitude and longitude coordinates of 80 districts and 888 villages in the Greater Bandung area, which are implemented as regional boundary polygons.

Another stage in data collection was an interview. The interview stage was used to obtain data related to experience and knowledge (Smith \& Sparkes, 2016). Interviews were carried out in the research, namely to the community directly, to get the desired feedback regarding the area mapping application. Several groups of people were interviewed, including entrepreneurs from 
the creative industry of MSMEs and those from education. Meanwhile, interviews with government officials were conducted with the Training Center for Cooperatives and MSMEs of the Office of Cooperatives and Small Businesses of West Java Province. Interviews with government agencies were conducted to obtain primary data sources related to spatial areas in the Greater Bandung area.

\section{Software Development Life Cycle Stages}

The next stage was the stage when building the system. This stage used the concept of a Software Development Life Cycle with a waterfall model. This waterfall stage is widely used when building a system, including monitoring applications (Afif et al., 2020), reporting (Rahayu, 2020), calculating (Rakhmat \& Rizki, 2020), and geographic information systems (Sukenda and Amanillah, 2020), such as in this research. Several stages were carried out: requirement definition, system and software design, implementation and unit testing, integration, system testing, and the last step, namely operation, and maintenance.

The first stage in the software development life cycle waterfall model was the requirements definition. Data in research related to mapping applications is the need for spatial data in the form of polygons containing the boundaries of the area displayed in the application. These areas are Bandung City, Bandung Regency, West Bandung, Cimahi City, and Sumedang Regency. The results of this stage obtained the latitude and longitude coordinates of the areas in Greater Bandung. The coordinates for each region are obtained from the government agency, in this case, the General Government and Public Housing. The coordinates obtained are of type Shapefile file with the format* $*$ shp.

The second stage in the waterfall model was system and software design. Some of the development tools used in this research were ArcGIS, leaflets, MySQL database, SQLYog, and Visual Studio. The specific steps to get the coordinate format displayed in the application are shown in Figure 2. 


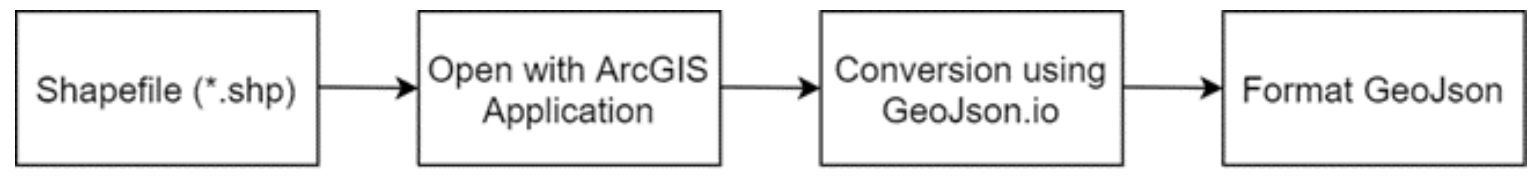

Figure 2 Stages of getting coordinated.

Shapefile file with * .shp extension is data that shows an object on the earth's surface, such as the shape of an island, administrative boundaries, rivers, and roads. In other words, shapefile files provide information about spatial or spatial data. Shapefiles are also often used for the benefit of building geographic information systems (Bazurto et al., 2019; Colvero et al., 2018) and geometry (Zhu et al., 2019). The shapefile file is opened using the ArcGIS application to obtain coordinate data, as shown in Figure 3.

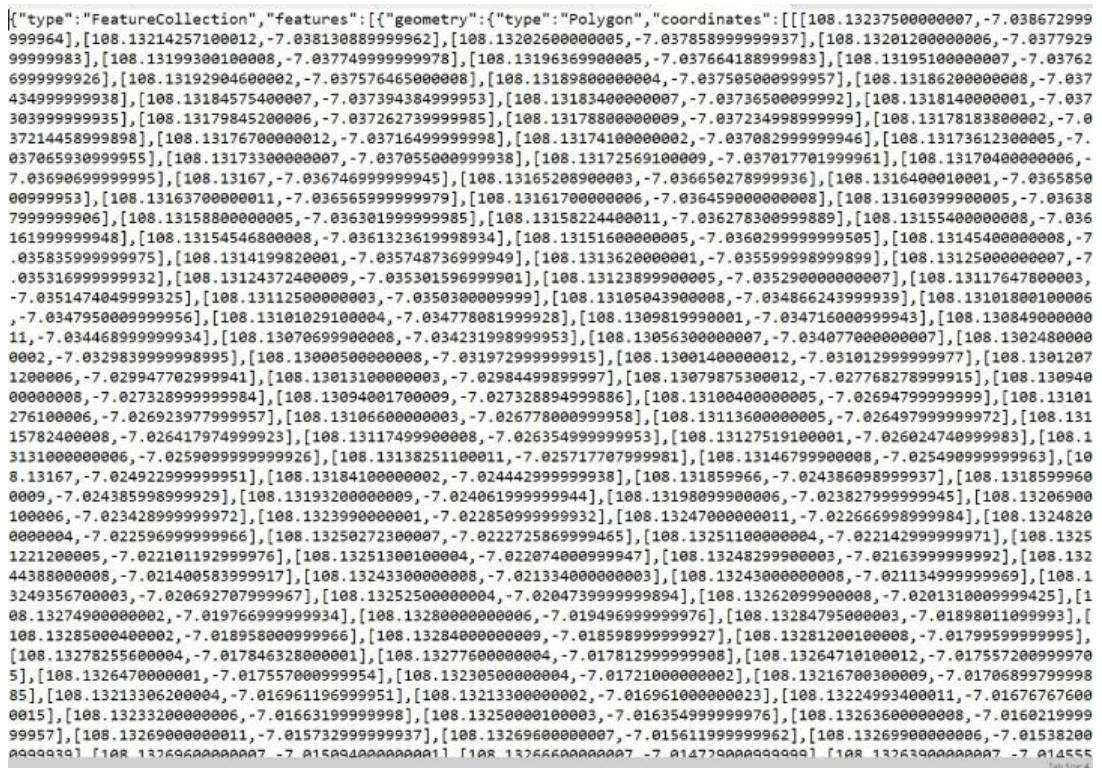

Figure 3 Stages of getting coordinates from shapefile.

The resulting coordinates can be used in the system. The next step is to convert them into GeoJson format so that they can be used to display spatial data (Horbiński \& Lorek, 2020; Zhu \& Tan, 2018). GeoJson also has good encoding and decoding performance when used in geographic information (Tong, 2018). This conversion process uses the tools from geojson.io, as shown in Figure 4. 


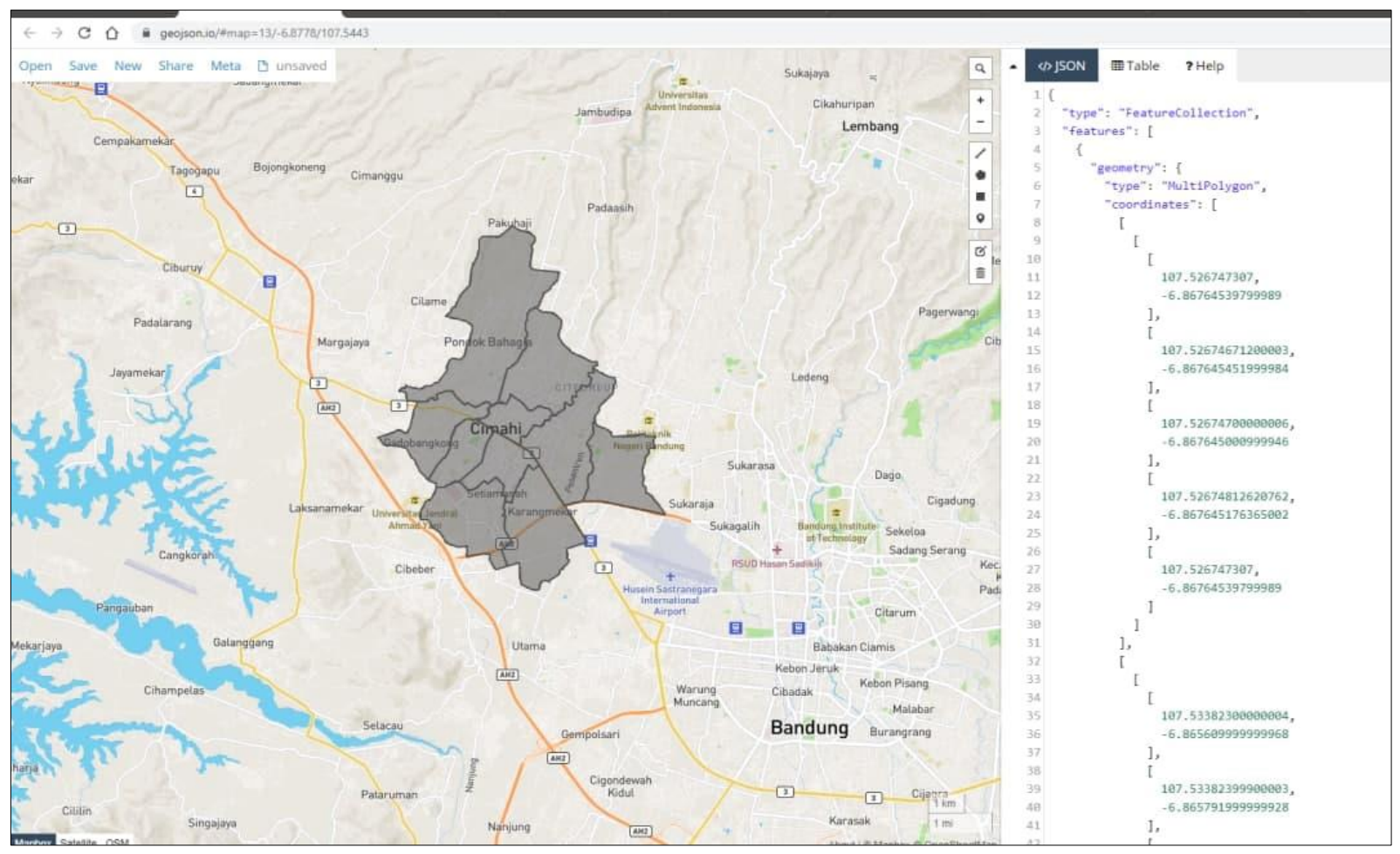

Figure 4 Stages of getting the Geojson format.

The next stage is system and software design. This stage is carried out the design from the procedure, functional, database, model to display design. After the design is complete, the next step is to implement it into a programming language. This application is web-based so that it can be accessed via the internet. The programming language used is the PHP programming language with MySQL database which can also be used for web-based applications (Kolios et al., 2018).

After properly implemented it into the programming language, the system testing stage is carried out to ensure that the implementation results are designed. Testing in this study was carried out by functionally testing each activity to be corrected again when some things were still wrong. The final step in the software development life cycle is operating the application and maintaining the application, especially data. 


\section{RESULTS AND DISCUSSION}

\section{Data Analysis for Polygon Map}

The mapping of districts in the Greater Bandung area is converting data on a conventional map into digital map data, made into a polygon. A polygon is a series of points in a sequence as a basic framework for mapping. Table 1 is sample data for mapping districts in the Greater Bandung area.

Table 1 Sample of district polygon

\begin{tabular}{|l|l|}
\hline District & Polygon Coordinate \\
\hline & $-7.027363,107.507526-7.027576,107.507333$ \\
& $-7.027661,107.507075-7.027619,107.506753$ \\
& $-7.027619,107.506496-7.027768,107.506238$ \\
& $-7.027884,107.506045-7.027970,107.505745$ \\
Soreang & $-7.028065,107.505487-7.028193,107.505294$ \\
& $-7.028427,107.505123-7.028640,107.504930$ \\
& $-7.028853,107.504715-7.029066,107.504522$ \\
& $-7.029322,107.504393-7.029556,107.504350$ \\
& $-7.029812,107.504221-7.030067,107.504221$ \\
& $-7.030344,107.504221-7.030557,107.504414$ \\
& $-7.030664,107.504629-7.030642,107.504908$ \\
& $-7.030621,107.505123-7.030685,107.505359$ \\
& $-7.031217,107.505509-7.031452,107.505337$ \\
& $-7.031665,107.505123-7.031750,107.504865$ \\
\hline
\end{tabular}

The application in this research can be accessed via the internet at the address http://wirausaha.web.id/view.php?menu=gis\&act=frm_gis as shown in Figure 5.

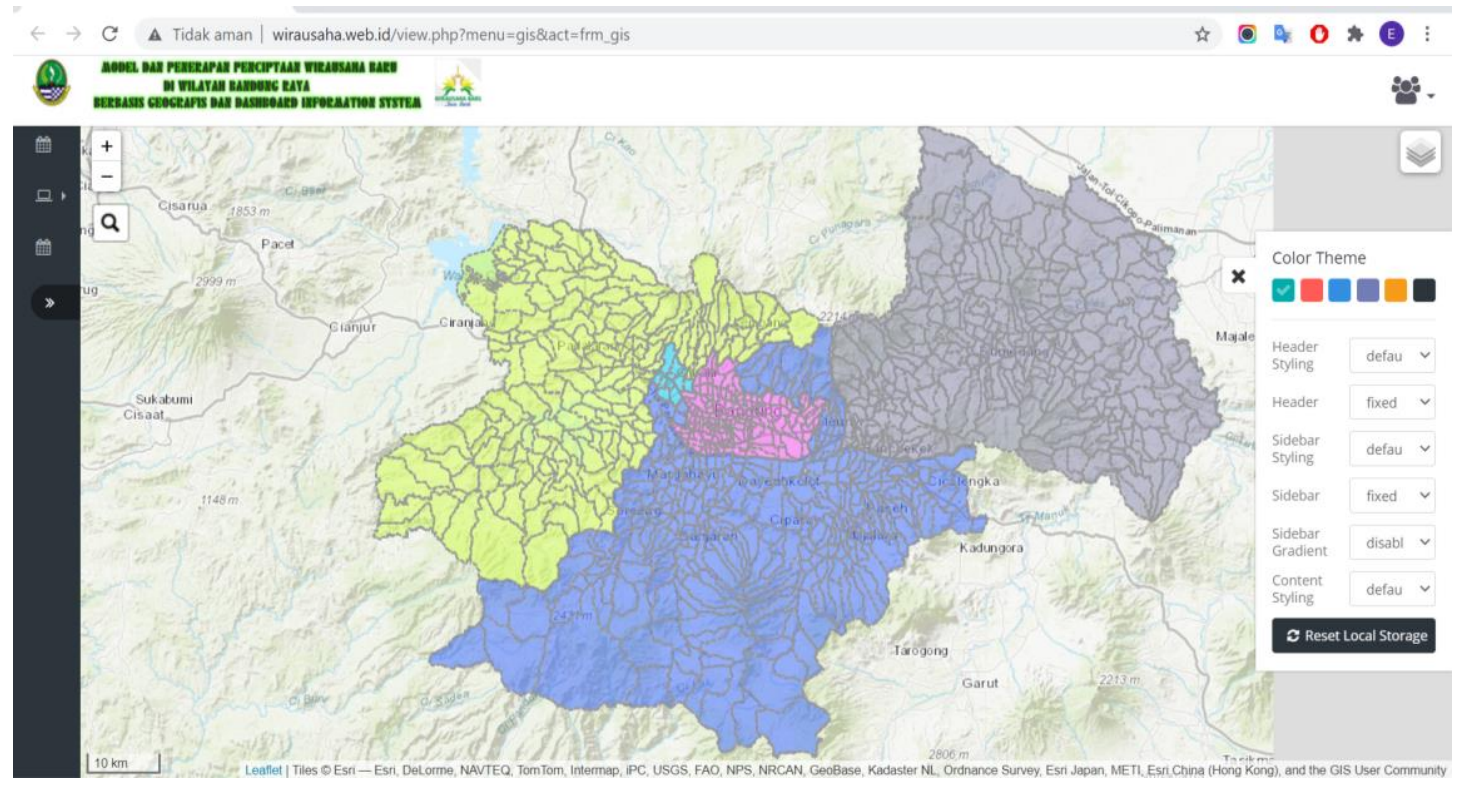

Figure 5 Map display results for the Greater Bandung Area. 
There are five regions shown in the application. The five regions are Bandung City with a pink map, Bandung Regency with a blue map, Cimahi City with a cyan map, West Bandung Regency with a green map, and the Sumedang Regency area with a gray map. To display the map in Figure 5, use a script like the following:

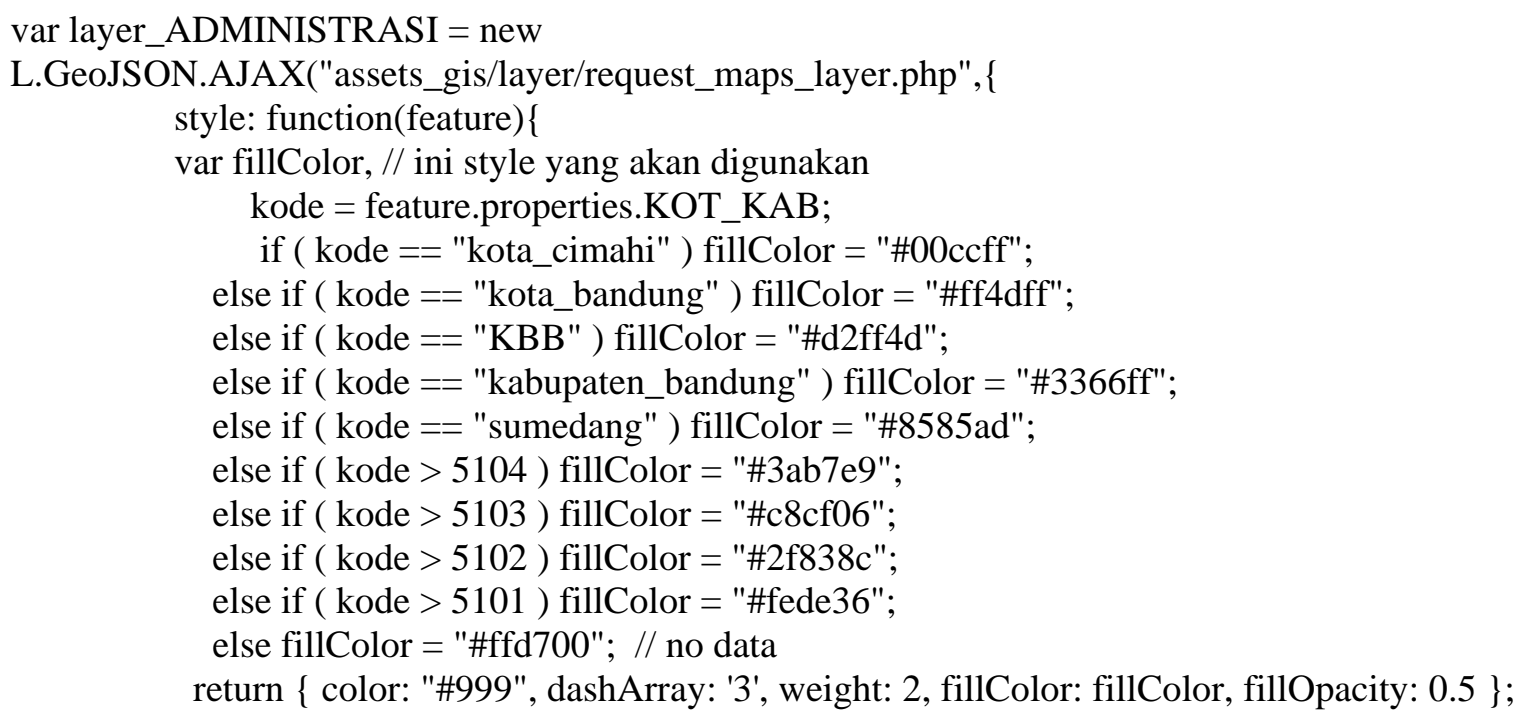

In addition to the territorial boundaries for each City and Regency, each village's boundaries also visible. If the boundary is selected, it will display information from the village's name, as shown in Figure 6.

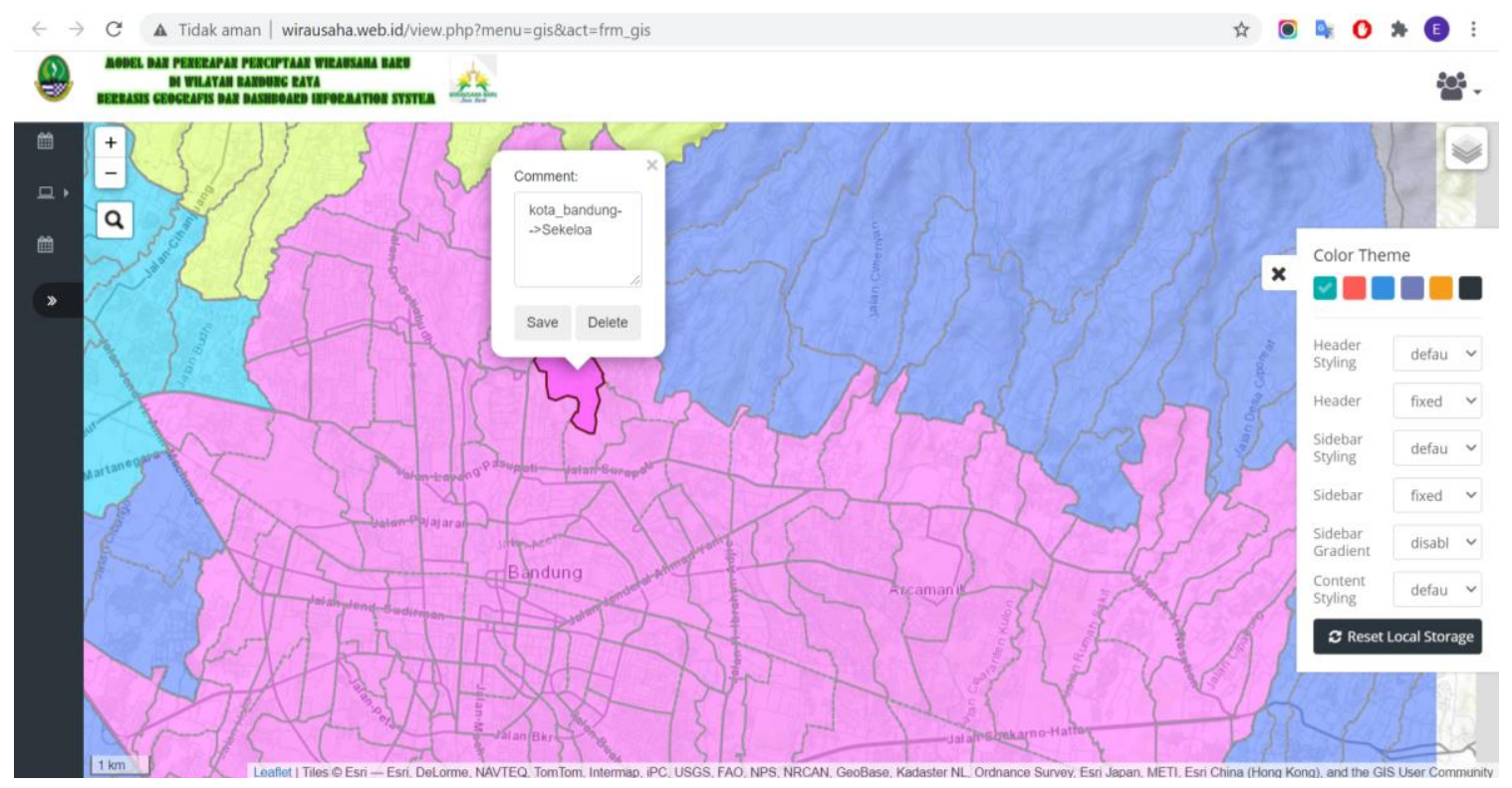

Figure 6 Information on the name of the village. 
There are a total of 888 villages in 80 sub-districts spread across the Greater Bandung area. Bandung Regency has 280 villages, Bandung City has 151 sub-districts, West Bandung Regency has 165 villages, Cimahi City has 15 villages, and Sumedang Regency has a total of 277 villages.

The hardware and software specifications used to implement the mapping application for the Greater Bandung area can see in Table 2.

Table 2 Hardware and Software specification.

\begin{tabular}{|l|l|}
\hline Hardware Type & Specification \\
\hline Processor & Shared Hosting \\
\hline Space Hardisk & $1,5 \mathrm{~GB}$ \\
\hline RAM & $1 \mathrm{~GB}$ \\
\hline Webserver & Apache \\
\hline PHP Version & 7.3 \\
\hline Apache version & 2.4 .46 \\
\hline MySQL Version & $10.3 .27-$ MariaDB \\
\hline Operating System & Linux \\
\hline
\end{tabular}

The web server used in this application is Apache because the apache web server has superior performance in data transfer (Setiawan et al., 2019). Application testing is carried out by functional testing, displaying the five regions in the Greater Bandung area and testing to display 888 villages. Based on BlackBox functional testing, 100\% of the area can display information as expected. The results obtained from the tests carried out show that each area can be displayed on the map well, including 888 villages. It can display area name information when the user selects a polygon area.

Applications in this research have been able to display spatial information from five regions in Greater Bandung. Further research is planned so that this application can display non-spatial data as needed. It displays non-spatial data that developed, displaying total entrepreneurial data and total tourism data in each region. Therefore, the community can see and know the potential of each selected area (Setiawan, 2016). 
Based on the research results obtained, several further potentials can be done so that the results of this research can be more useful for society and government. The availability of spatial information from a total of 888 districts in the Greater Bandung Area can be used more specifically for broader interests such as the distribution of the MSMEs industry, the distribution of industrial potential for each region, and tourist attractions. Of course, to complete the data, there must be further coordination with the relevant government as the data provider.

Figure 7 shows the comparison of the time it takes to display the map for the first time, while Figure 8 shows the time it takes to display the map after the map has been opened. The browsers used on personal computers are Google Chrome, Mozilla Firefox, and Microsoft Edge, while the browsers used on smartphones are Google Chrome, Mozilla Firefox, and the default browser.

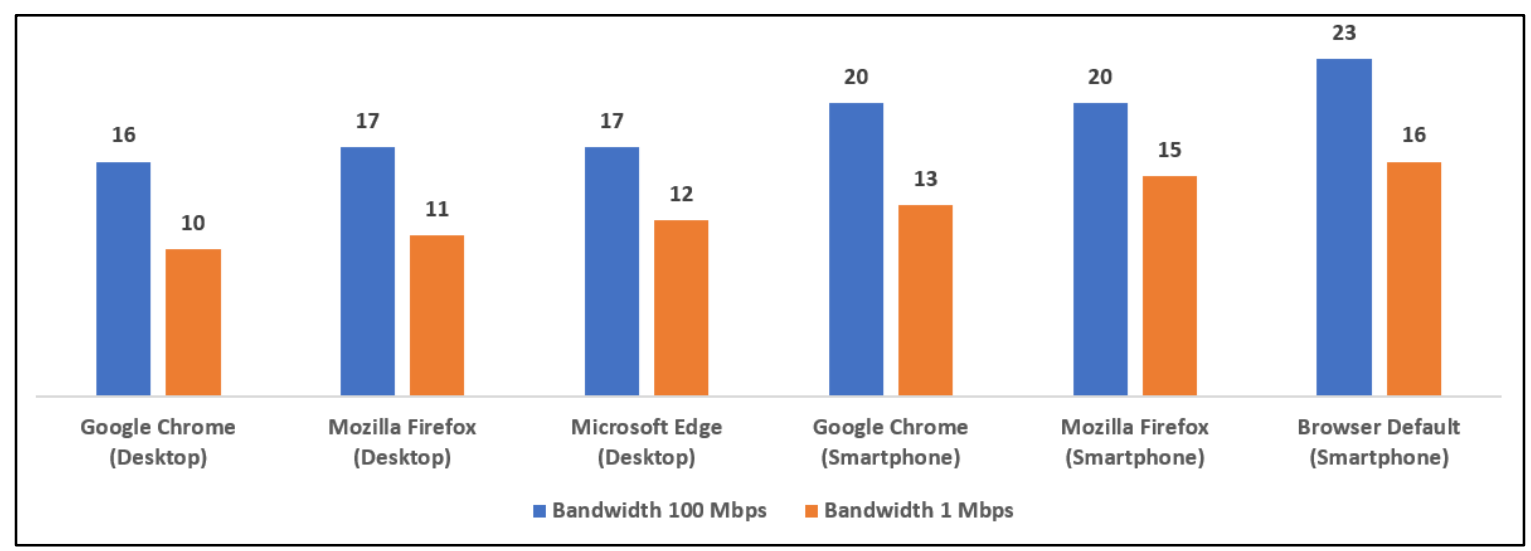

Figure 7 Comparison time for view map first time

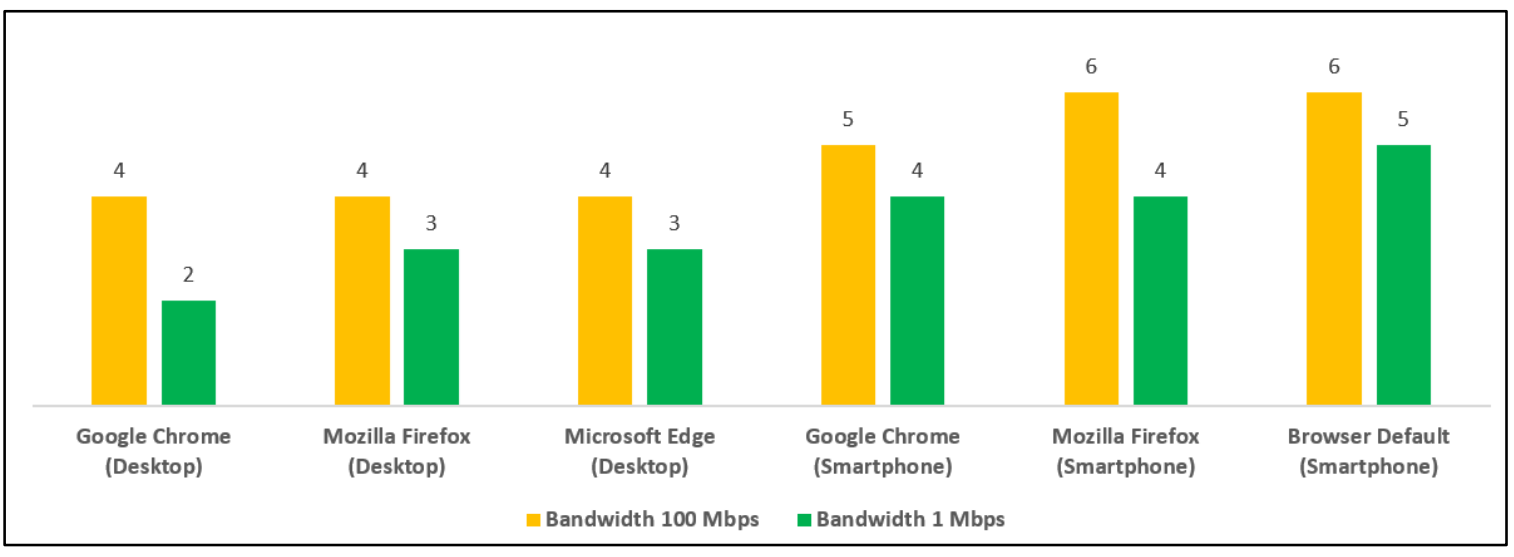

Figure 8 Comparison time for the view when maps have been opened 
Based on the comparison of loading times between the firsttime opening maps and opening maps for the second time, there is a significant difference in load time to display maps. When the map was first opened, it took a long time, from 16 seconds to 23 seconds, for the map to appear. However, after the map has been opened, it does not take long to display the map again, about 2 seconds to 6 seconds, because the map data is stored in the browser's cache (Kim et al., 2017).

Several things are of technical concern, namely due to the large amount of spatial data displayed. The application requires a longtime lag, which is about 23 seconds, using a bandwidth of $100 \mathrm{Mbps}$ and a browser on a smartphone to display spatial information for all areas. This lag is because it takes time for the system to load all the information in GeoJson. Besides, the information displayed does not take too long. It is hoped that the implementation of applications related to the spatial use of better server and network specifications. It is recommended to use a Virtual Private Server to get better performance (Balen et al., 2020), not using the concept of a shared hosting server.

The maps produced in this study can be used for various purposes. Based on the results of a questionnaire to 130 respondents by asking the public's willingness to get additional information from an area on the map. The results show that the highest percentage of people who want information from an area is information related to culinary, tourism, and entertainment. The results of the percentage of desired information can be seen in Figure 9.

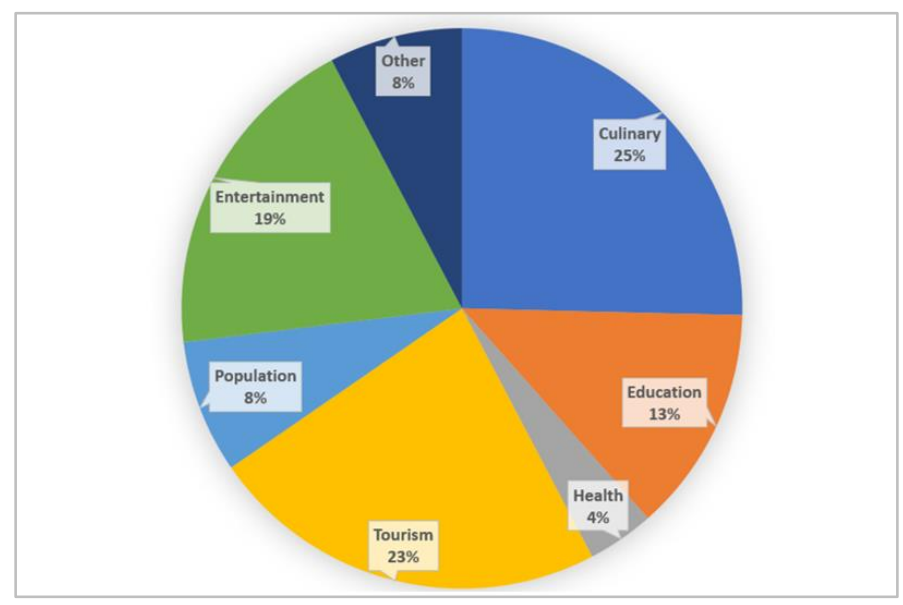

Figure 9 Percentage of community willingness to know more information 


\section{CONCLUSION}

Based on the research results that have been carried out, it is concluded that the mapping application can help know the spatial data of each region which, if developed with non-spatial data, can be known the distribution of potentials contained in each region. The number of maps and coordinates that need to be displayed on the map, making the map display displayed for the first time takes quite a long time, ranging from 10 to 23 seconds depending on the device, browser, and bandwidth the internet connection used. Further research is also needed to accommodate the community's desire to get complete information about an area displayed on the map, which can indirectly help the government increase the resources and potential of an existing area in the Greater Bandung area.

\section{ACKNOWLEDGMENTS}

Authors wishing to acknowledge UNIKOM for publication this paper, and Ministry of Education and Culture (Kemendikbud), and Ministry of Research and Technology/National Research and Innovation Agency (Kemenristek/BRIN) for help and support this research using grant Penelitian Riset Terapan Year 2019-2021 Contract for Multiple Years No. 7/E/ KPT/2019 and 019/SP2H/LT-AMAND/LL4/2020, and B/112/E3/RA.00/2021.

\section{REFERENCES}

Afif, A. N., Noviyanto, F., Sunardi, S., Akbar, S., and Aribowo, E. 2020. Integrated application for automatic schedule-based distribution and monitoring of irrigation by applying the waterfall model process Bulletin of Electrical Engineering and Informatics, 9(1): 420-426.

Alkhalidi, M.W., Nadeak, B., and Sayuthi, M. 2020. Sistem informasi geografis pemetaan wilayah penyalahgunaan narkoba mengunakan metode SOM (Self-Organizing Map) studi kasus: kabupaten aceh tenggara, Building of Informatics, Technology and Science (BITS), 2(1): 1-9.

Balen, J., Vajak, D., and Salah, K. 2020. Comparative performance evaluation of popular virtual private servers Journal of Internet Technology, 21(2): 343-356 . 
Bazurto, J., Falcones, V., Gámez, M. R., and Arvelo, M. 2019. Geographic information system for manabí sustainable development. International research journal of management, IT and social sciences, 6(6): 17-28.

Brovelli, M. A., Minghini, M., Kilsedar, C.E., Zurbarán, M., Aiello, M., and Gianinetto, M. 2017. Migrate: a foss web mapping application for educating and raising awareness about migration flows in Europe The International Archives of Photogrammetry, Remote Sensing and Spatial Information Sciences, 42: 51.

Colvero, D.A., Gomes, A., da Cruz Tarelho, L., de Matos, M., and dos Santos, K. 2018. Use of a geographic information system to find areas for locating of municipal solid waste management facilities Waste Management, 77: 500-515.

Dede, M., Setiawan, I., Mulyadi, A. 2017. Application GIS to analyse crime risk in Bandung. The 2nd International Conference in Sociology Education (ICSE), 1: 597-602.

Falah, F., and and Zeinivand, H. 2019. Gis-based groundwater potential mapping in khorramabad in lorestan, Iran, using frequency ratio (fr) and weights of evidence (woe) models. Water Resources, 46(5): 679-692.

Horbiński, T., and Lorek, D. 2020. The use of Leaflet and GeoJSON files for creating the interactive web map of the preindustrial state of the natural environment. Journal of Spatial Science. 1-17.

Humphries, G., Naveen, R., Schwaller, M., Che-Castaldo, C., McDowall, P., Schrimpf, M., and Lynch, H. 2017. Mapping application for penguin populations and projected dynamics (MAPPPD): data and tools for dynamic management and decision support, Polar Record, 53(2): 160-166.

Kim, T., Thirumaraiselvan, V., Jia, J., and Li, C. 2017. Caching geospatial objects in web browsers. ACM SIGSPATIAL International Conference on Advances in Geographic Information Systems. 1-4

Kolios, S., Karvelis, P., and Stylios, C. 2018. Web-based geographical information system for real-time flood monitoring of the river arachthos in epirus region, Greece. International Conference on Advances in Satellite and Space Communications SPACOMM 2018: 28- 
32.

Marlintha, A. B., Irawan, B., and Latuconsina, R. 2017. Design and implementation of smart village mapping geographic information system based web in the cinunuk village. In 2017 IEEE Asia Pacific Conference on Wireless and Mobile (APWiMob): 66-71.

Maulana, H., Andriana, R., and Kanai, H. 2019. Development of the 3-Dimensional Map in the Bandung Regency Government Complex. In IOP Conference Series: Materials Science and Engineering, 662(2): 022113. IOP Publishing.

Orlando, R., Fojan, P., Mo, J., Bergsøe, N. C., and Afshari, A. 2020. Single-Stage Air Filtration of Particles and Gaseous Contaminants in Buildings: A Literature Study. In IOP Conference Series: Earth and Environmental Science, 588(3): 032073. IOP Publishing.

Rahayu, T. K. 2020. Application Report Process Of Islamic School Based On Pesantren Boarding Using Waterfall Model. In Journal of Physics: Conference Series, 1569 (2): 022025. IOP Publishing.

Rakhmat, Edy., and Rizki, F. 2020. Zakat calculation system based on desktop application using waterfall model in serang district baznas 1st International Multidisciplinary Conference on Education, Technology, and Engineering (IMCETE 2019). Atlantis Press.

Saxena, M. 2019. Survey of traditional waterfall model in SDLC. Current Trends in Information Technology, 9(1) 4-6.

Setiawan, E. B. 2016. Sistem informasi geografis untuk pemetaan potensi usaha industri kreatif Jurnal CoreIT: Jurnal Hasil Penelitian Ilmu Komputer dan Teknologi Informasi, 2(1): $1-7$.

Setiawan, E. B., Setiyadi, A., and Wahdiniwaty, R. 2019. Quality Analysis of Mobile Web Server. In IOP Conference Series: Materials Science and Engineering, 662(2): 022043. IOP Publishing.

Setiawan. I, Dede. M., Sugandi. D., and Widiawaty MA 2019. Investigating urban crime pattern and accessibility using geographic information system in Bandung City $K n E$ 
Social Sciences: 535-548.

Smith, B., and Sparkes, A. 2016. Qualitative interviewing in the sport and exercise sciences. Routledge handbook of qualitative research in sport and exercise: 103-123.

Sukenda, and Amanillah, A. 2020. Web of city or province natural resources using geographic information system-base (GIS). International Journal of Psychosocial Rehabilitation, 24(2).

Syaifudin, Y. W., Puspitasari, D., Ariyanto, Y., and Ariyanto, R. 2019. The design of road conditions mapping system by utilizing openstreetmap spatial data. In IOP Conference Series: Materials Science and Engineering, 523(1): 012045. IOP Publishing.

Tong, I. 2018. The comparative study between GML and GeoJSON in coding, decoding and transmission. Beijing Surveying and Mapping, 3(8).

Tsutsumida, N., Percival, J., Murakami, D., Yoshida, T., and Nakaya, T. 2019. Interactive mapping for geographically weighted correlation in big census data International Cartographic Association, 1.

Ullerud, H., Bryn, A., Halvorsen, R., and Hemsing, L. 2018. Consistency in land-cover mapping: influence of field workers, spatial scale and classification system Applied Vegetation Science 21(2): 278-288.

Zhu, J., Wang, X., Wang, P., Wu, Z., Kim, M. J. 2019. Integration of BIM and GIS: Geometry from IFC to shapefile using open-source technology. Automation in Construction. 102: 105-119.

Zhu, Z., and Tan, J. 2018. A multi-source heterogeneous vector space data integration scheme based on geojson. 26th International Conference on Geoinformatics, 1-4. 